\title{
Újabb késő rézkori kocsimodell a Kárpát-medencéből
}

\author{
BONDÁR MÁRIA \\ MTA Bölcsészettudományi Kutatóközpont Régészeti Intézet \\ H-1014 Budapest, Úri u. 49., e-mail: bondar.maria@btk.mta.hu
}

BondÁr, M.: A newly found Late Copper Age Wagon Model from the Carpatian Basin.

Abstract: This study offers a brief overview of the main directions in the research of prehistoric wagon models and presents a new Late Copper Age model.

Keywords: Late Copper Age, settlement finds, prehistoric wagon models, chronology

Az emberiség történetében a tüz felfedezéséhez mérhető, hasonlóan nagy jelentőségű innováció a kerék és a kocsi megalkotása volt. A kerék a földművelésben is óriási változásokat hozott, az ökrök vontatta kerekes ekével könnyebben, gyorsabban lehetett a korábbinál nagyobb földterületet megművelni, így a termésmennyiség, a terület eltartó képessége is jelentősen megnövekedett.

A kerék alapvető fontosságú volt a kocsi innovációjához is. A korai Y, majd A formájú csúszkák (amelyeket egyszerüen elkészíthető technikájuk és praktikusságuk miatt még napjainkban is változatlan formában használnak), ${ }^{1}$ majd az ezekre helyezett ládák vezettek a tömör fakerekü nehézszekerek megalkotásához. Az „igazi” kocsi (true chariot) a küllős kerekü, könnyü mozgású két vagy háromkerekü szálítóeszköz, valamint a modernkor hintói: megannyi megjelenési formája az állatok vontatta kerekes járműnek, amelyek más-más technikai kivitelt, fogatolási módozatot és egyéb kellékeket igényelnek. Különböznek a kocsi elé fogott igavonó állatban is: a nehézszekereket egy vagy két ökör vagy szamár húzta, míg a könnyedebb kocsik elé lova(ka)t fogtak. A mitológiában vízimadarak röpítik az égi jármüvet a szakrális szférába.

A szekér a közlekedésben, a szállításban, a szomszédos és távoli közösségek egymás közötti kapcsolatában, a gazdasági és kulturális egymásra hatásban, szokások, anyagi javak, különleges termékek átvételében is óriási jelentőségủ volt. Nem véletlen, hogy a kerék és a kocsi szimbolikus tartalommal is bírt és a mitológiában is komoly szerepet játszott a világ szinte minden táján. Nemcsak a mondákban találkozunk ezekkel a jelképekkel, hanem különböző ábrázolásokon is nyomon követhetjük meglétüket. A legkorábbi kerék és kezdetleges kocsiábrázolások sziklarajzokon találhatók Európában, elsősorban a mai Svájc, Németország és Olaszország területéről ismertek. A leletanyagban megtalálhatók a

1 NADLER 2002. Nadler, M. 1991. nyarán K-Törökországban fotózta le több faluban is a szénahordáshoz használt, ökrök vontatta, $A$ alakú, kétkerekü, fából készült szállítóeszköz használatát és készítési fázisait. járomba fogott ökröcskék agyagból vagy fémböl elkészített miniatür kisplasztikái és az agyag kerékmodellek is. A késő rézkorban megjelennek az agyagból készített kocsimodellek, amelyek telepröl és temetkezésekböl egyaránt ismertek, kultikus tartalmuk vitathatatlan. A korai és középső bronzkori kultúrákban a szakrális jelentőség mellett megjelenik a hétköznapi funkció (gyerekjáték) is és új elemként feltünik a madár-ember-kocsi metafora. A korábban csak a kocsira és a kocsit húzó igavonó állatokra kiterjedő ábrázolások mellett feltűnik a mitológiai tartalmú madár, amely az égbe, a szakrális szférába repíti a kocsit és vele az élő vagy már halott embert. ${ }^{2}$ A késő bronzkorban változik a korábbi tartalom, a kocsi tömegáruvá válik, szakrális jelentősége nem a miniatür változatok megalkotásában jelenik meg, hanem a kiváltságosok valós kocsitemetkezéseiben ölt testet. Ez a szokás a vaskorban is megmarad, de megtaláljuk az edényekre rajzolt vagy kerékre helyezett urna formájában ábrázolt kocsikat is, csakúgy, mint a híres napszekereket.

A kocsi jelentősége a mindennapi életben vitathatatlanná vált az évszázadok során. A kezdeti misztifikáció után széles körben elterjedt használati, kereskedelmi vagy éppen harci eszközzé vált.

Nem feledkezhetünk el azonban arról a tényröl, hogy e különleges tárgyak (az agyagból vagy fémből megformált kocsiszobrocskák, vagy a protoméhoz tartozó állatalakok) és az igazi kocsik fából készült kerekei, vagy a valós kocsik, kocsitemetkezések, a keréknyomok, az útmaradványok stb. előkerülése esetleges, elsősorban a véletlennek köszönhető, így ismereteink ugyancsak mozaikosak, az egykori valóságnak csak csipkeszerü rajzolatát kapjuk, amelyből különböző tendenciákat próbálunk megállapítani.

E napjainkig ható és fejlődő innováció régészeti emlékei sokrétűek, könyvtárnyi mennyiségű szakirodalom foglalkozik a téma különböző aspektusaival (tárgyi emlékek és típus leírások, közlekedési, kereskedelmi, archaeozoológiai vonatkozások, társadalmi fejlettség, közösségek kapcsolatai, eredetkérdés, irodalmi, nyelvészeti és mitológiai vonatkozások, halottkultusz, nomádok és városlakók kapcsolata, harcászat, szórakoztatás, ábrázolásmódok stb.), felsorolni is nehéz lenne valamennyit.

2 A középső bronzkorban kialakult madárkultusz nemcsak a madarak által húzott kocsiábrázolásokban (bird-chariot) hanem önállóan is megjelenik madár alakú aszkoszok és csörgők is nagy számban kerültek elő a különböző telepeken és temetőkben. 
A négykerekű szekér felfedezésének időpontjával, első megjelenési helyének meghatározásával, szélesebb körü elterjedésével, az egykori életben betöltött szerepével, jelentőségével könyvek és tanulmányok sora foglalkozott már. Míg a 20. század második felében inkább a kultikus vonatkozások és az elterjedés topográfiája foglalkoztatta a kutatókat, napjainkban a kocsi-kereskedelem-állattartás-gazdasági változások vizsgálatára vannak kísérletek, amely témaköröket az utóbbi évtizedben több konferencián és tematikus kötetben is bemutatták a különböző szakterületek kutatóii. ${ }^{3}$ Hangsúlyossá vált a „másodlagos termékek forradalma (Secondary Products Revolution)"4 kapcsán az állatok húsának, tejének vagy bőrének és igavonó ereje többszöri felhasználhatóságának felismerése, és olvashatjuk ennek az elméletnek a kritikáját is. ${ }^{5} \mathrm{~A}$ kocsikutatás napjainkban a nyelvészet és az indoeurópai eredetkérdésben is fontos tényezővé vált. ${ }^{6}$

$A z$ elmúlt évtizedekben számos kérdésre igyekezett választ találni a kutatás. A különböző szekérábrázolások, a valós kocsimaradványok előkerülése és a leletek radiocarbon keltezése napjainkra jelentősen módosította a korábbi kronológiát, s újabb problémákat vetett fel. Máig nem eldöntött, hogy egy centrumból terjedtek-e el a kocsik vagy a poligenetikus fejlődés a valószínübb. Nyitott kérdés még az is, hogy a Közel-Keletröl vagy a Pontus-vidékről került-e Európába e jelentős innováció, a négykerekű nehézszekér, avagy éppen fordítva, Európából terjedt dél felé a nyersanyag-kereskedelemmel és az állatok másodlagos hasznosításával is összefüggésbe hozható jármü. $A$ szekér széleskörü elterjedését egyre inkább a gazdasági élet által kikényszerített innovációnak tartja a legújabb kutatás, amely csak ott honosodott meg, ahol erre megvolt a társadalmi-gazdasági igény. ${ }^{7}$ Míg a Kr. e. 4. évezredben a kocsi még valószínüleg presztízstárgy vagy kultikus kellék volt, a 3. évezred közepétől már a közel-keleti urbanizációval összefüggésbe hozható, a kereskedelemben nélkülözhetetlen szállítóeszközként funkcionált.

A tömör kerekü nehézszekerek elöfordulása alapján három, közel egykorú nagy centrum rajzolódik ki a térképen: a Közel-Kelet, az eurázsiai sztyeppe-vidék valamint Európa középső része, elsősorban a Kárpát-medence. A kocsival összefüggésbe hozható egyéb bizonyítékok egészen az Északi-tengerig vezetnek és időben ma már korábbra helyezik a kerék és kocsi ismeretét. Ma már a neolitikum végétöl egyre több jól keltezhető adat (tömör fakerekek, fatengelyek, kerékvágásnyomok, fából készített kocsiút maradványok stb.) bizonyítja, hogy a kétvagy négykerekü szekér már Kr. e. 4. évezred közepétöl ismert volt Európa nagy részén.

3 Sherratt 1983, Achse, Rad und Wagen 1986, Greenfield et al. 1988, Woytowich 1995, ANTHONY-VINOgRAdOV 1995, SHERRATt 2003, Wegzeiten 2004, Rad und Wagen 2004, Premiers chariots, premiers araires 2006, RAHMSTORF 2006, Between the Aegean and Baltic Seas 2007, Anthony 2007, Primas 2007, BaKels 2009.

4 Sherratt 1983, Greenfield et al. 1988, Duerr 2007.

5 összefoglaló áttekintés a témáról: VosteEN 1996.

6 Anthony 1990, Anthony 1995, Raulwing 2000, Anthony 2007, KUZ'MINA 2007

7 RAHMSTORF 2006, 76, RuOFF 2006, 139-140
A kocsi korai ismerete Európában több adattal is bizonyítható. Az ikonográfiai adatok (sziklarajzokon megjelenített kerekes járművek Svájc, Németország, Olaszország szikláin), a fakerekek (Dánia, Németország, Horvátország), a nemrégiben előkerült flintbeki (Németország) keréknyom, a hollandiai fatörzsekből kirakott útmaradvány, az agyagból készített kerék és kocsimodellek, a kocsik elé fogott állatok kisplasztikái egyértelművé teszik e fontos innováció széles körü európai elterjedését és korai meglétét ebben a térségben.

A rézkori kerekek feldolgozása $A$. Dinunak köszönhető, aki közreadta a 4. évezrednél korábbi (Cucuteni, Gumelniţa, Petresţi) kultúrák kocsikerék leleteit Románia területéről. ${ }^{8}$ Dinu már ekkor bizonyítottnak látta, hogy a kerekes kocsi jóval korábbi, mint azt általában feltételezi a kutatás, véleménye azonban sokáig nem talált követőkre. A szíriai (Aruda) és törökországi (Arslantepe) miniatür agyagkerekek ${ }_{14} \mathrm{C}$-es keltezése megerősítette Dinu véleményét, az említett kocsikerekek ugyanis a közismert bronocicei edényre karcolt kocsiábrázolással egykorúak, azaz korábbiak, mint az ismert agyag kocsimodellek. ${ }^{9} \mathrm{Az}$ új adatokat közlő szerzői team a késő rézkori Kárpát-medencéből is említ még néhány kocsikereket: Ózd-Kőaljatetőről Banner nyomán, valamint a coţofeni kultúrából Tebea lelőhelyről és több kocsikereket Vučedol-Várhegyről. ${ }^{10}$

2001-ben Ilon Gábor publikált egy, a kocsi ismeretének általánosan elfogadott időpontjánál korábbi, a késő lengyeli-Balaton-Lasinja kultúra telepén előkerült agyag kocsikerék töredéket Szombathelyröl. ${ }^{11}$

2002-ben Lubljana környékén látott napvilágot egy fa kocsikerék és tengely maradványa. A leletek a Kr. e. 4. évezredből származnak, a Retz-Gajary és a badeni kultúra közötti időszakból, radiocarbon és dendrokronológiai keltezési eredményeik az előzetes beszámoló megjelenésekor még nem voltak meg, ${ }^{12}$ a kísérő kerámialeleteket tipokronológiai alapon $A$. Velušček a badeni kultúra legelejére keltezte. ${ }^{13}$

2009-ben az Olzreuter Ried (Baden-Württemberg tart. Németo.) lelöhelyen végzett ásatásokon találtak négy fából készült keréktöredéket. A legnagyobb $58 \mathrm{~cm}$ átmérőjü volt. Ezek a kerekek a kétkerekü, $A$ formájú szénaszállító eszközhöz tartozhattak. Az elsődleges dendrokronológiai eredmények alapján a fakerekek Kr. e. 2897-ből származnak. Az Alpoktól északra jelenleg ez a legkorább fakerék maradvány az ásatók szerint. A leletek között egy kis agyag kerék töredéke is elökerült, amely négykerekü, a Kárpát-medencéből ismert agyag kocsimodellre utal. A fakerekek keltezése jól illeszkedik a kocsimodellek keltezéséhez, amelyet a badeni kultúrához köt a kutatás. ${ }^{14} \mathrm{Az}$ ásatáson előkerült agyag kerékmodell töredéke bizonyítja, hogy a valós kerekek mellett megformálták azok miniatür mását is.

\footnotetext{
8 DINU 1981.

9 BAKKER et al. 1999, 781.

10 BAKKER et al. 1999, 781.

11 ILON 2001, 476, I. t., ILON 2004, VI. t. 1.

12 VELUŠČEK 2002.

13 VELUŠČEK 2006, 44

14 SCHLICHTHERLE 2010
} 
Nemrégiben egy újabb lelet bizonyította a kerekes járműnek a bolerázi időszaknál korábbi ismeretét: 2008ban a Vatikánban bemutatott „Cucuteni-Tripolje: az ősi Európa nagy civilizációja” c. kiállításon szerepelt egy szarvasmarha stilizált szobrocskája, amely négy tömör keréken gördülö, lábait a két tengelyhez rögzített ökör vontatta szekér sajátos egyvelege. ${ }^{15}$

Jelen tanulmányban egy új kocsimodellt mutatunk be, amely nemrégiben került elő Kaposvár közelében (Somogy m.) egy nagyfelületű ásatáson. A telepgödörből származó makett a kísérőleletek alapján - jelen ismereteink szerint - a legkorábbi agyag kocsimodellek közé tartozik a Kárpát-medencében, amelyet a bolerázi időszakra keltezhetünk. ${ }^{16}$

1999-2000-ben a 61. sz. út Kaposvárt elkerülö szakszának toponári csomópontjában az ún. 61/2. sz. lelőhelyen (korábban Toponár-Lovaspálya néven ismert hely) Bárdos Edith és Gallina Zsolt végzett megelöző feltárásokat. Az átkutatott 53000 m²$^{2}$ en 3300 különböző korú objektum került elő (lengyeli kultúra, Balaton-Lasinja kultúra, badeni kultúra, kora bronzkor, mészbetétes edények népe kultúrája, kelta, Árpádkor). ${ }^{17}$ A lelőhely a csomópont délnyugati negyedében, a Kaposvárról Szántódra vezető út nyugati oldalán, a PATE lovardájától dél-délnyugatra kb. 100-150 m-re, a Deseda-pataktól keletre 3-400 m-re, egy észak-déli irányú, hosszú dombhát keleti lejtőjén helyezkedett el. A feltárt nagykiterjedésű területen több korszak objektumait bontották ki. Az 597. objektumból egy kocsimodell töredékei láttak napvilágot. ${ }^{18} \mathrm{~A}$ rekonstruált agyag kocsi fotója - tévesen - „Balatonőszöd” lelőhellyel szerepel a kaposvári múzeum centenáriumi kiadványában egy színes képen. ${ }^{19}$

\section{A kocsimodell}

Vöröses barna színü, szögletes kocsiszekrény négy töredékéből rekonstruálták a kocsimodellt (1. kép) a kaposvári múzeum restaurátorai. A töredékek a kocsiszekrény alsó részéből származnak, a kocsi négy sarkát és teljes magasságát valamint az alján lévő bütykök indítását adják meg biztosan. Egy töredék a kocsiszekrény sarkát is megőrizte, a felcsúcsosodó peremmel és a kocsi elején lévő applikáció letört maradványával. Oldalai

15 http://scribalterror.blogs.com/scribal_terror/2008/09/a-cucutenitripol...

16 A Szombathelyröl közölt agyag kerékmodell ugyan korábbi a szekér maketteknél, de a kerékröl önmagában nem dönthető el, hogy kocsialkatrész vagy kerekes eke tartozéka volt-e.

17 Bárdos Edith szíves szóbeli közlése. A lelőhelyröl mindössze Gallina Zs. rövid ismertetése állt rendelkezésemre (GALLINA 2000, 251). Ezúton köszönöm Honti Szilviának a lelöhely leírásában és a leletanyag és dokumentáció előkeresésében nyújtott mindennemű segítségét.

18 Ezúton is szeretnék köszönetet mondani Bárdos Edithnek, hogy engedélyezte a kocsimodell közlését.

19 A centenáriumi kötet „Jubileumi kötet. 1909-2009. 100 éves a Múzeum” c. kiadvány az SMK 19 (2010). kötete, ennek 59. oldalán, számozatlan színes fotón látható a jelen tanulmány témáját adó kocsimodell, a boglárlellei (a kötetben Balatonlelle) és balatonberényi (a kötetben tévesen Balatonendréd képaláirással szereplö) példányokkal együtt. trapéz alakúak, alja téglalap formájú. A kocsimodell alján lévő bütyöklábak kiegészítések a hasonló kocsimodellek alapján, amelyeket az eredeti darabokon megfigyelhető ívek, és az applikációt tartalmazó saroknál megmaradt töredékrész teljesen alátámaszt.

A kocsimodell felülete kissé elnagyolt, égetése sem tökéletes. Három oldala biztosan díszített, a negyediknél ez csak valószínűsíthető. Alja díszítetlen. A kocsiszekrényt borító díszítés három vízszintes sorba bekarcolgatott függőleges vonalkákból állt össze.

Méretek: hosszabbik oldala fölül: $9,5 \mathrm{~cm}$, alul $8,3 \mathrm{~cm}$. Rövidebb oldala fölül: $8,5 \mathrm{~cm}$, alul $7 \mathrm{~cm}$. Magassága (a lábak nélkül) $5 \mathrm{~cm}$. Egyedi azonosítója: 98/102.597.264.

\section{A kíséröleletek}

Az 597. objektumból és a vele egybeásott 1020. objektumból a lengyeli kultúra és a bolerázi csoport leletei kerültek elő. Az 597. objektumot a késő rézkorban beleásták az 1020. objektumba (lengyeli kultúra). Az 597. objektum a felszínen $293 \times 220 \mathrm{~cm}$, alja $267 \times 210$ $\mathrm{cm}$. $130 \mathrm{~cm}$ mély volt. A leleteket ásónyomonként csomagolták, a két különböző korú objektum egymásba ásottsága miatt az egyes ásónyomokban is vegyesen vannak a lengyeli és bolerázi leletek.

A bolerázi csoport jellegzetes töredékei az alábbi típusokhoz tartoznak:

Tálak: tölcséres nyakú, fordított csonkakúpos testü, peremük alatt fényezett, hasukon durvított felületü, a perem belső oldalán széles sávban vagy ferdén kannelúrázott tálak (2. kép 7,9). Ugyanilyen típusú díszítetlen változatok (3. kép 1-2). Gömbszelet alakú, fényezett felületü tálak töredékei, a peremen függölegesen benyomkodott pontsordísszel (2. kép 8).

Fazekak: peremük alatt kettős, bevagdosott bordával díszített, durvított hasú fazekak (2. kép 5) és egy füles fazék töredéke is elökerült, a fül két oldalán a perem alatt bevagdosással, ez alatt benyomott pontokkal díszítve (3. kép 6).

Hombárok: sötétszürke, a vállukon kettős, benyomkodott vékony bordával díszített hombárok.

Amforák: sötétbarna, vékony falú, rövid nyakú, hordó testü amforák töredékei, peremük alatt kétsoros, bevagdosott bordadísszel, testükön bekarcolt halszálkamintával díszítve (2. kép 1-2, 4). Egy másik változatnál a nyakon van körbefutó, bevagdosott bordadísz (2. kép 3).

Bögrék, korsók, kancsók: nagyon kevés bögre, korsó vagy kancsómaradvány került elő az objektumból (3. kép 5). Néhány vékony falú, díszítetlen oldaltöredék és kancsóhoz tartozó széles szalagfül (3. kép 3-4) jelzi ezeknek az edényeknek az előfordulását a gödörben.

Miniatür edény: fordított csonkakúp alakú miniatür tálka, vállán körbefutó, bevagdosott díszítéssel, d: 6 $\mathrm{cm}$ (2. kép 6).

A késő rézkori és kora bronzkori kocsimodellekkel már több tanulmányban is foglalkoztam, ${ }^{20}$ a késő rézkori kocsikról - éppen egy Somogy megyei (Balatonberény)

20 BONdÁR 1990, BondÁR 1992, BondÁR 2004, BondÁr 2006. A jelen kézirat leadása után (2011. eleje) egy magyar és egy angol nyelvü kismonográfiában részletesen feldolgoztam a témát BoNDÁR 2012, BONDÁR 2012a. 
kocsimodell apropóján - nemrégiben írtam nagyobb áttekintést. ${ }^{21}$ Ezt követően Kovács Tibor publikált egy újabb késő rézkori (bolerázi) kocsimodellt, ${ }^{22}$ majd Kövecses Varga Etelka adott közre három makett töredéket és egy kerékmaradványt Esztergom-Szentkirály lelőhelyröl, klasszikus badeni időszakból. ${ }^{23}$

A fent részletesen leírt kaposvári kocsimodell a bolerázi időszakhoz köthető, jellegzetesen ahhoz a típushoz tartozik, amelyen kerekeket még nem ábrázoltak, de a kocsi húzására használt igavonó állat szimbolikusan megjelent az elölapon. Sajnos, ennek csak a helye van meg, a letörött állatfej nem került elő.

$\mathrm{Az}$ ismert kocsimodellek alapján már korábban is megállapíthattuk, hogy a késő rézkoriak a Kárpátmedence középső részén fordulnak elö koncentráltan. ${ }^{24}$ Pest, Komárom-Esztergom és Somogy megyéből több darab is ismert, egyetlen példányt sem közöltek viszont még az Alföldről vagy Észak-Magyarországról. $A z$ agyag kocsik többsége egyelőre a bolerázi időszakra keltezhető. ${ }^{25} \mathrm{Az}$ immáron 18 ismert kocsiszoborból 11 makett a bolerázi csoport (Balatonberény, ${ }^{26}$ Balatonlelle/korábban Boglárlelle, ${ }^{27}$ Kaposvár (1. kép), Moha, ${ }^{28}$ Mödling, ${ }^{29}$ Pilismarót, ${ }^{30}$ Plessing, ${ }^{31}$ Radošina, ${ }^{32}$ Chorvátsky Grob, ${ }^{33}$ és Pezinok ${ }^{34}$ ), 6 pedig (Budakalász $2 \mathrm{db},{ }^{35}$ Szigetszentmárton, ${ }^{36}$ Esztergom $3 \mathrm{db}^{37}$ ) a klaszszikus badeni, 1 a Coţofeni kultúra lelete.

A késő rézkori agyag makettek nyitott tetejüek, szögletes kocsiszekrényük van, általában rombusz oldalakkal, ahol a felső él hosszabb, mint az alsó. Eltérő díszítésük, peremkiképzésük arra utal, hogy a valós kocsik nem voltak egyformák, különböző technikával és anyagból készültek. Korábban az agyagmodellek és a logika segített abban, hogy következtessünk az igazi szekerek anyagára, készítési technikájára. Ma már az időközben előkerült faleletek alapján könnyű megállapítani, hogy a való életben használt kocsik alkatrészeinek (kocsiszekrény, tengely, kerekek) legföbb anyaga valamilyen fa volt. Nyilvánvaló, hogy a tengelyt és a tengellyel ekkor még együtt forgó kerekeket deszkából készítették, de a kocsikast többféle módon is megformálhatták: fából (hosszabb-rövidebb deszkadarabokból), lécekre erősített vesszőfonatból, vagy e kettő kombinációjából. Az sem elképzelhetetlen, hogy a kas oldala kisebb agyag-

21 BONDÁR 2004. (a kutatástörténet és a legfontosabb irodalom áttekintésével)

22 Moha lelőhelyröl került elő egy gazdagon dísztett darab. Magángyüjteményben van. Kovács 2006, Abb. 1.

23 KöVECSES VARGA 2010. (A kötet egyelöre csak egy példányban látott napvilágot, a cikk elektronikus változatát ezúton is köszönöm a kötet szerkesztőjének Tari Editnek.)

24 BONDÁR 2004, 15. kép

25 BONDÁR 2004, 15. o.

26 BONDÁR 2004, 5. kép 1, 6. kép

27 ECSEDY 1982, 8. kép

28 Kovács 2006, Abb. 1

29 RutTKay 1995, Abb. 7. 3

30 BondÁr 1990, Abb. 7. 3.

31 RUtTKAY 2000, Taf. 5. 63

32 PaVÚKOVÁ-BÁRTA 1977, Abb. 7.

33 FARKAŠ 2010, Fig. 4

34 FARKAŠ 2010, Figs 2-3.

35 SoPRoNi 1954, 6. t. 5. (158. sír), 6. t. 1. és 7. t. 1-2 (177. sír)

36 KaliCZ 1976, Fig. 3.

37 KöVECses VARga 2010, 14-15. kép téglákból készült, és azt fával, vesszőfonattal egybeszerkesztve alakították ki a kocsiszekrényt.

A bolerázi időszak legtöbb kocsimodelljénél a kocsiszekrény alja egyenes, kerékre vagy tengelyre utaló jelzést nem találunk rajtuk (Boglárlelle, Mödling, Pilismarót, Plessing, Radošina). Mindössze két makettnél jelölték a tengelyeket tartó szerkezeti elemet is (Balatonberény, Moha). Valószínü, hogy az egyik pezinoki töredék és a kaposvári darab is ebbe a típusba tartozik, a makett töredéken található bütyökindítás alapján. A klasszikus badeni időszak kocsiábrázolásainál már egyértelmüen megjelenik a tengely és a kerék jelzése különböző módon. A budakalászi 177. sír modelljénél ${ }^{38}$ a füles kocsiszekrény alsó része összeillesztett deszkalapokból áll, amely a bekarcolt vonalak alapján egyértelmü. A kerekeket tartó tengelyt is bekarcolt vonalakkal jelölték. Hasonlóak az esztergomi darabok is, ${ }^{39}$ de itt a tengelyt egy kis borda imitálja. ${ }^{40} \mathrm{~A}$ budakalászi 158 . sír ugyancsak füles kocsiedénye kis bütyöklábakon áll, ${ }^{41}$ valószínüleg ezek voltak a tengelyre utaló jelzések. Az esztergomi makettek egyike is ebbe a típusba sorolható. ${ }^{42} \mathrm{~A}$ szigetszentmártoni kocsimodellnél két, külön rátett, kerékben végződő henger jelenti a tengelyeket. ${ }^{43}$ A kerék és tengely illesztéséről, valós megformálásról biztos adatokat szolgáltat a Ljubljana mellett talált valós kocsialkatrész. ${ }^{44}$

A bolerázi modelleken a kocsiszekrény díszítése nem egységes. Többségükön többsoros, bekarcolt zegzugmintát találunk (Boglárlelle, ${ }^{45}$ Mödling, ${ }^{46}$ Pleissing, ${ }^{47}$ Balatonberény, ${ }^{48}$ Pezinok ${ }^{49}$ ). A Mohán előkerült példányon ${ }^{50}$ kisebb négyzet, háromszög illetve rombusz alakú mezőkbe rendezett, bekarcolt vonalkák adják a gazdag díszítést. Hasonlóan díszített egy pezinoki töredék is. ${ }^{51}$ A kaposvári makettet három párhuzamos sorban bekarcolt rövid vonalkák díszítik (1. kép), csakúgy, mint a Chorvátsky Grobon talált töredéken. ${ }^{52}$ A Radošinán elökerült protomén csak a peremen fut körbe három pontsorból álló díszítés. ${ }^{53}$ Díszítetlen a Pilismarót-basaharci példány. ${ }^{54} \mathrm{~A}$ klasszikus badeni időszak modelljei is különböző díszítésüek, egyedül a budakalászi 158. sír bütyöklábakon álló makettje díszítetlen. ${ }^{55}$ Bekarcolt farkasfogminta található a budakalászi temető 177 . sírjának kocsimodelljén ${ }^{56}$ és a szigetszentmártoni példány peremén. ${ }^{57} \mathrm{Ez}$ utóbbinál a rövidebb és hosszabb olda-

\footnotetext{
38 BONDÁr 2004, 1. kép 1c

39 Kövecses VARga 2010, 14. kép 1-2.

40 Kövecses Varga 2010, klny. 4. o.

41 BONDÁr 2004, 1. kép 2 .

42 KöVecses Varga 2010, 15. kép

43 BONDÁR 2004, 1. kép 3b

44 VELUŠČEK 2006, Fig. 3- Fig. 5

45 BONDÁR 2004, 3. kép

46 BONDÁR 2004, 4. kép 1

47 BONDÁr 2004, 4. kép 2

48 BONDÁR 2004, 6. kép

49 FARKAŠ 2010, Fig. 3.

50 KovÁcs 2006, Abb. 1.

51 FARKAŠ 2010, Fig. 2.

52 FARKAŠ 2010, Fig. 4

53 BONDÁR 2004, 2. kép 1a-b.

54 BONDÁR 2004, 2. kép 3a-c.

55 BONDÁR 2004, 1. kép 2

56 BONDÁR 2004, 1. kép 1c

57 BONdÁr 2004, 1. kép 3a.
} 
lak találkozásánál lévő éleknél farkasfog és bekarcolt „létraminta" található. ${ }^{58}$ Ugyanilyen mintát láthatunk az egyik esztergomi darabon is, ${ }^{59}$ míg a két másik esztergomi töredéken bekarcolt farkasfogminta van. ${ }^{60}$

A kocsiszekrények peremének kiképzése is eltérő a bolerázi modelleken. A radošinai darab előlapján félköríves végződés van, talán hasonló lehetett a pilismaróti is. ${ }^{61} \mathrm{~A}$ boglárlellei, mödlingi, pleissingi és mohai darabok, a kaposvárihoz hasonlóan felcsúcsosodó peremben végződnek, míg a balatonberényi kocsiszekrény egyenes peremü. A badeni modellek kocsiszekrényeinek oldala ívelt, ezáltal felcsúcsosodó sarkúak.

Négy bolerázi kocsin a kocsit húzó, igavonó állatok (Radošina, ${ }^{62}$ Boglárlelle, ${ }^{63}$ Moha, ${ }^{64}$ Kaposvár) plasztikus ábrázolásként jelennek meg. Ezeken a kocsikon az elölap teljesen eltér a többi oldaltól, a későbbi harciszekerek mellvédszerű előlapjára emlékeztet. Sajnos, a mödlingi, pleissingi, balatonberényi, pilismaróti, pezinoki és a Chorvátsky Grobon talált makettek töredékei nem elegendőek annak eldöntéséhez, vajon ezek is protoméként értelmezhetőek-e.

A klasszikus badeni időszak modelljeinek közös jellemzője a négyszögletes kocsiszekrény rövidebb oldalán lévő, a perem fölé emelkedő nagyívű fül, amely véleményem szerint a kocsik elé fogott igavonó állatok fogatolásának módjára is utalhat, nemcsak füles edényként értelmezhető, ahogyan ezt eddig tettük. ${ }^{65}$

A Kárpát-medencében előkerült késő rézkori agyagmodellek kultikus tartalmát nem vitatjuk. ${ }^{66} \mathrm{Ha}$ megvizsgáljuk még azt is, hogy e kocsimodellek és az egyéb különleges kultikus tárgyak (pl. idolok, kebles edények)

58 BONDÁR 2004, 2. kép 3b.

59 KöVECSES VARGa 2010,12. kép

60 Kövecses Varga 2010, 9-10. és 15. kép

61 BONDÁR 2004, 2. kép 3c

62 BONDÁR 2004, 2. kép 1a-b

63 BONDÁR 2004, 3. kép

64 Kovács 2006, Abb. 1.

65 LitTAUer-Crouwel 1996, Fig. 2.: Közép-Anatóliából, Kültepéről ismert egy a II. évezred elejéröl származó kocsiábrázolás, amelynek alapján ezt az ötletet felvetem. A domborművön négyszögletes, kétkerekü (küllös) kocsin áll a kocsihajtó. A kocsiszekrény aljából induló kocsirúdhoz két lovat fogtak be, a lovak szájához rögzített kötőfék a kocsihajtó kezébe kunkorodik vissza. Ezt a fogatolási módot láthatjuk esetleg leegyszerüsítve a füles kocsiedényeken.

66 A bronzkorban már a gyerekjáték funkció is elfogadható lehetőség a kis agyagmodelleknél (BondÁR 1990, OLEXA 1983). elterjedése hogyan viszonyul egymáshoz, azt tapasztaljuk, hogy bizonyos területeken - nagyjából hasonló mértékben kutatott térségekben - koncentráltabban jelentkeznek ezek a ritka leletek, mint máshol. Ez a tény azt jelezheti, hogy ezek a régiók fontosabb szerepet kaptak a badeni kultúra életében, azaz a települések között valamiféle hierarchia, státuszbeli különbség volt. Lehetséges, hogy a kultikus leletek koncentráltabb elöfordulása hatalmi vagy kultikus központra, gazdasági centrumra utal, ahol - a közel-keleti településekhez hasonlóan - nagyobb létszámú közösségek éltek, itt zajlott a kereskedelem, és a közösségi összetartozás rendszeres szertartásai, ünnepei is. ${ }^{67}$ Egyelöre nem tudjuk bizonyítani, hogy a Közel-Kelet fejlett városállamaihoz hasonló települések lettek volna már a badeni kultúra idején térségünkben is, a különleges leletek (ritka, kultikus tartalmú vagy presztízstárgyak és jelenségek) előfordulásában megfigyelhető koncentrálódás azonban valószínűleg nem a véletlen műve. ${ }^{68}$ Természetesen ez a felvetés további elmélyült kutatást igényel. A településhálózat és temetkezések elemzése, a környezet által meghatározott gazdasági keretek, kereskedelmi kapcsolatok pontos feltérképezése, a földművelés és állattartás arányának meghatározása, demográfiai következtetések levonása, további presztízs elemek kimutatása közelebb vihet bennünket a késő rézkori közösségek egymáshoz viszonyított státuszának pontosabb körvonalazásához, egy-egy, a kutatás szempontjából szerencsés kontextusú leletegyüttes pedig a hitvilág, a kognitív szféra újabb mozaikjának helyreillesztéséhez is hozzásegíthet. A jövőben talán a nagyfelületű ásatások feldolgozása választ adhat arra a kérdésre, hogy megvoltak-e a Kárpát-medencében azok a társadalmigazdasági igények, amelyek minden új befogadására alkalmassá tették az itteni közösségeket vagy épp ellenkezőleg, az itteni közösségek különleges innovációi jutottak el távolabbi vidékekre, ahol a gazdasági fejlettség már készen állt ezen felfedezések integrálására.
67 BONDÁR 2007.
68 BONDÁR 2008, 180.

\section{Irodalom}

Achse, Rad und Wagen 1986: Fünftausende Jahre Kultur- und Technikgeschichte. (Hrsg. Treue, W.) Göttingen 1986.

Anthony, D. W. 1990: The Baby and the Bathwater. American Anthropologist. New Series 92/4: 895-914.

Anthony, D. W. 1995: Horse, wagon and chariot: Indo-European languguages and archeology. Antiquity 69: 554-565.

Anthony, D. W. 2007: Horse. The Wheel and Language. How BronzeAge riders from the Eurasian Steppes shaped the Modern World. Princeton and Oxford.

Anthony, D. W. \& Vinogradov, N. B. 1995: Birth of the Chariot. Excavations east of the Ural Mountains reveasl traces of the first two-wheeled high-performance vehicles. Archaeology 48/2: 36-41.
BAKELs, C. C. 2009: The Western European Loess Belt. Agrarian History, $5300 \mathrm{BC}-\mathrm{AD}$ 1000. Heidelberg.

Bakker, J. A., KRuk, J., Lanting, A. E. \& Milisauskas, S. 1999: The earliest evidence of wheeled vehicles in Europe and the Near East. Antiquity 73: 778-790.

Between the Aegean and Baltic Seas 2007: Prehistory across borders. Proceedings of the International Conference. Bronze and Early Iron Age Interconnections and Contemporary Developments between the Aegean and the Regions of the Balkan Peninsula, Central and Northern Europe. University of Zagreb, 11-14 April 2005. (Eds Galanaki, I., Tomas, H., Galanakis, Y. \& Laffineur, R.) Liège. (Aegeum 27) 
BónA, I. 1960: Clay Models of Bronze Age Wagons and Wheels in the Middle Danube Basin. Acta Archaeologica Academiae Scientiarum Hungaricae 12: 83-111.

BONDÁR, M. 1990: Das frühbronzezeitliche Wagenmodell von Börzönce. Communicationes Archaeologicae Hungariae pp. 77-91.

BONDÁR, M. 1992: Kora bronzkori kocsimodell Börzöncéröl. - Das frühbronzezeitliche Wagenmodell von Börzönce. Zalai Múzeum 4: 113-127

BondÁR, M. 2004: A kocsi a késő rézkori Európában. - Der Wagen im spätkupferzeitlichen Europa. Archaeologiai Értesítő 129: 5-34.

BONDÁR, M. 2006: Le chariot en Europe au Chacolithique récent. In: Premiers chariots, premiers araires. La diffusion de la traction animale en Europe pendant les IV et III millénaires avant notre ère. (Sous la direction de Pétrequin, P. - Arbogast, R. M. Pétrequin, A. M. - Willigen, S. - Bailly, M.) Paris, pp. 225-237.

BoNDÁR, M. 2007: A kultuszélet kellékei a késő rézkorban. Előadás az Őskoros Kutatók V. Összejövetelén. Debrecen 2007. márc. 12-14.

BondÁR, M. 2008: The Paraphernalia of Cult Life in the Late Copper Age. Acta Archaeologica Academiae Scientiarum Hungaricae 59: 171-181.

BondÁR, M. 2012: Agyag kocsimodellek a Kárpát-medencében (Kr. e. 3500-1500) Budapest.

BoNDÁR, M. 2012a: Prehistoric wagon models in the Carpathian Basin (3500-1500 BC). Budapest. (Arcaheolingua. Series Minor 32).

CHILDE, G. 1954: The Diffusion of Wheeled Vehicles. EthnographischArchäologische Zeitschrift 2: 1-17.

DINU, M. 1981: Clay Models of Wheels discovered in Copper Age Cultures of Old Europe mid-fifth Millenium B.C. The Journal of Indo-European Studies 9: 1-14.

DuerR, J. von 2007: Zum Beginn der Milchnutzung in Mitteleuropa. Ethnographisch-Archäologische Zeitschrift 48: 335-373.

ECSEDY I. 1982: Későrézkori leletek Boglárlelléröl. - Late Copper Age finds from Boglárlelle. Janus Pannonius Múzeum Évkönyve 26 (1981) 73-95.

FAnsA, M. \& Burmeister, S. 2004: Rad und Wagen. Der Ursprung einer Innovation Wagen im Vorderen Orient und Europa. Austellung vom 28. März bis 11. Juli 2004. (Hrsg.: Fansa, M. - Burmeister, S.) Mainz am Rhein. (Beiheft der Archäologische Mitteilungen aus Nordwestdeutschland 40.)

FARKAŠ, Z. 2010: Rectangular vessels (wagon models) of the Boleráz group from Pezinok and Chorvátsky grob. pp. 435-447. In: Panta rhei. Studies on the Chronology and Cultural Development of south-Eastern and Central Europe in earlier Prehistory. Presented to Juraj Pavúk on the Occasion of his $75^{\text {th }}$ Birthday. (ed Suteková, J. - Pavúk, P. - Kalábková, P. - Kovár, B.) Comenius University in Bratislava and Archaeological centre, Olomouc. Bratislava.

GaLLINA Zs. 2000: Elözetes jelentés a Kaposvárt elkerülő 61-es számú főút 2. és 3. lelőhelyének régészeti feltárásáról. Somogyi Múzeumok Közleményei 14: 251-258.

Greenfield, H. J., Chapman, J., Clason, A. T., Gilbert, A. S., Hesse, B. \& Milisauskas, S. 1988: The Origins of Milk and Wool Production in the Old World: A Zooarchaeological Perspective from the Central Balkans [and Comments]. Current Anthropology 29/4: 573-593.

ILON G. 2001: Újabb adat a réz- és bronzkori kocsik Kárpát-medencei történetéhez. Vasi Szemle 55: 474-485.

ILON G. 2004: Szombathely őskori településtörténetének vázlata. Avagy a római kor elött is volt élet. - Outline of the pre-historic settlement of Szombathely or life before the Roman Age. Szombathely. (Öskorunk 2)

KALICZ, N. 1976: Ein neues kupferzeitliches Wagenmodell aus der Umgebung von Budapest. Festschrift für R. Pittioni zum siebzigsten Geburstag. Archaeologia Austriaca. Beiheft 13: 188-202.

KovÁcs, T. 2006: Bisher Unnbekennte kupfer- und bronzezeitliche Wagenmodelle aus Ungarn. Acta Archaeologica Academiae Scientiarum Hungaricae 57: 35-45.

KöVECSES VARGA E. 2010: Kocsimodell-töredékek EsztergomSzentkirályról. In: Tanulmánykötet Horváth István 70 éves születésnapjára. (szerk.: Lázár Sarolta - Tari Edit) Esztergom. 61-71.
Kuz'minA, E. F. 2007: The Origin of the Indo-Iranians. Leiden-Boston. (Leiden Indo-European Etymological Dictionary Series Vol. 3.)

LitTauer, M. A. - Crouwel, J. H. 1996: The origin of the true chariot. Antiquty 70: 934-939.

NADLER, M. 2002: Anatolische Impressionen. In: Rad und Wagen. zur Frage früher Transportmittel nördlich der Alpen. (Hrsg. Königer, J. - Mainberger, M. - Schlichtherle, H. - Vosteen, M.) Freiburg i Breisgau, pp. 93-98. (Hemmenhofener Skripte 3)

NĚmejcová-PAVúkovÁ, V. \& BÁRTA, J. 1977: Äneolitische Siedlung der Boleráz-Gruppe in Radošina. Slovenská Archeológia 25: 433447.

PREMIERS CHARIOTS, PREMIERS ARAIRES 2006: La diffusion de la traction animale en Europe pendant les IVè et IIIè millénaires avant notre ère. (Ed.: P. Pétrequin, R-M. Arbogast, A-M. Pétrequin, S. van Willigen, M. Bailly). Paris. (Collection de Recherches Archéologiques. Monographies 29.)

PRIMAS, M. 2007: Innovationstransfer von 5000 Jahren. Knotenpunkte an Land- und Wasserwegen zwieschen Vorderasien und Europa. In: Eurasia Antiqua. Mainz am Rhein, pp. 1-19. (Zeitschrift für Archäologie Eurasiens 13.)

RAD Und WAgensee FANSA - BURmeISTER 2004

RAHMSTORF, L. 2006: Zur Ausbreitung vorderasiatischer Innovationen in die frühbronzezeitliche Ägäis. Prähistorische Zeitschrift 81: 4996.

Raulwing, P. 2000: Horses, Chariots and Indo-Europeans. Foundations and Methodes of Chariotry Research from the Viewpoint of Comparative Indo-European Linguistics. Budapest. (Archaeolingua. Series Minor 13)

Ruoff, U. 2006: Roues et chars: les plus ancienes découvertes de Suisse. In: Premiers chariots, premiers araires 2006, pp. 133 140.

RutTKAY, E. 1995: Boleráz-Gruppe. In: Lenneis, E. - NeugebauerMaresch, C. - Ruttkay, E.: Jungsteinzeit im Osten Österreich. St. Pölten-Wien, pp. 145-160. (Forschungsberichte zur Ur- und Frühgeschichte 17).

RutTKAY, E. 2000: Siedlungsfunde der Boleráz-Gruppe aus Wien und dem nordtransdanubischen Niederösterreich. Fundberichte aus Österreich 38: 609-622.

SherRATT, A. 1983: The secondary exploitation of animals in the Old World. Word Archaeology 15/1: 90-104.

SHERRATT, A. 2003: The Horse and the Wheel: the Dialectics of Change in the Circum-Pontic Region and Adjacent Areas, 4500-1500 BC. In: Prehistoric steppe adaptation and the horse (eds by Levine, M. - Renfrew, C. - Boyle, K.) Cambridge, pp. 233-252. (McDonald Institute Monographs)

Schlichtherle, H. 2010: Als die ersten Räder rollten ... Räder der Jungsteinzeit aus dem Olzreuter Ried bei Bad Schussenried. Denkmalpflege in Baden-Württemberg 3, 140-144.

Soproni S. 1954: A budakalászi kocsi. Folia Archaeologica 6: 29-36.

VELUŠČEK, A. 2002: Ostanski eneolitskega voza z Ljubljanskega barja. - The remains of an Eneolithic cart from Ljubljana Marshes. Archeološki Vestnik 53: 51-57.

VELUŠČEK, A. 2006: Une roue et un essieu néolithiques dans le marais de Ljubljana (Slovénie). In: Premiers chariots, premiers araires 2006, pp. 39-45.

VosteEn, M. 1996: Unter die Räder gekommen. Untersuchungen zu Sherratts „Secondary products revolution”. Bonn. (Archäologische Berichte 7)

WEGZEITEN 2004: Archäologie und Strassenbau. Begleitbuch zur Ausstellung des Bundesdenkmalamtes, Abteilung für Bodendenkmale in Kooperation mit der Niederösterreichischen Landesregierung, Gruppe Straße in der Kartause Mauerbach, 20. Mai bis 30. September 2004. Wien 2004. (Fundbericht aus Österreich Materialhefte Reihe A. Sonderheft 1)

Wortowitsch, E. 1995: Die Wagen der Schweiz in der europäischen Bronzezeit. Helvetia Archaeologica 26: 83-351. 


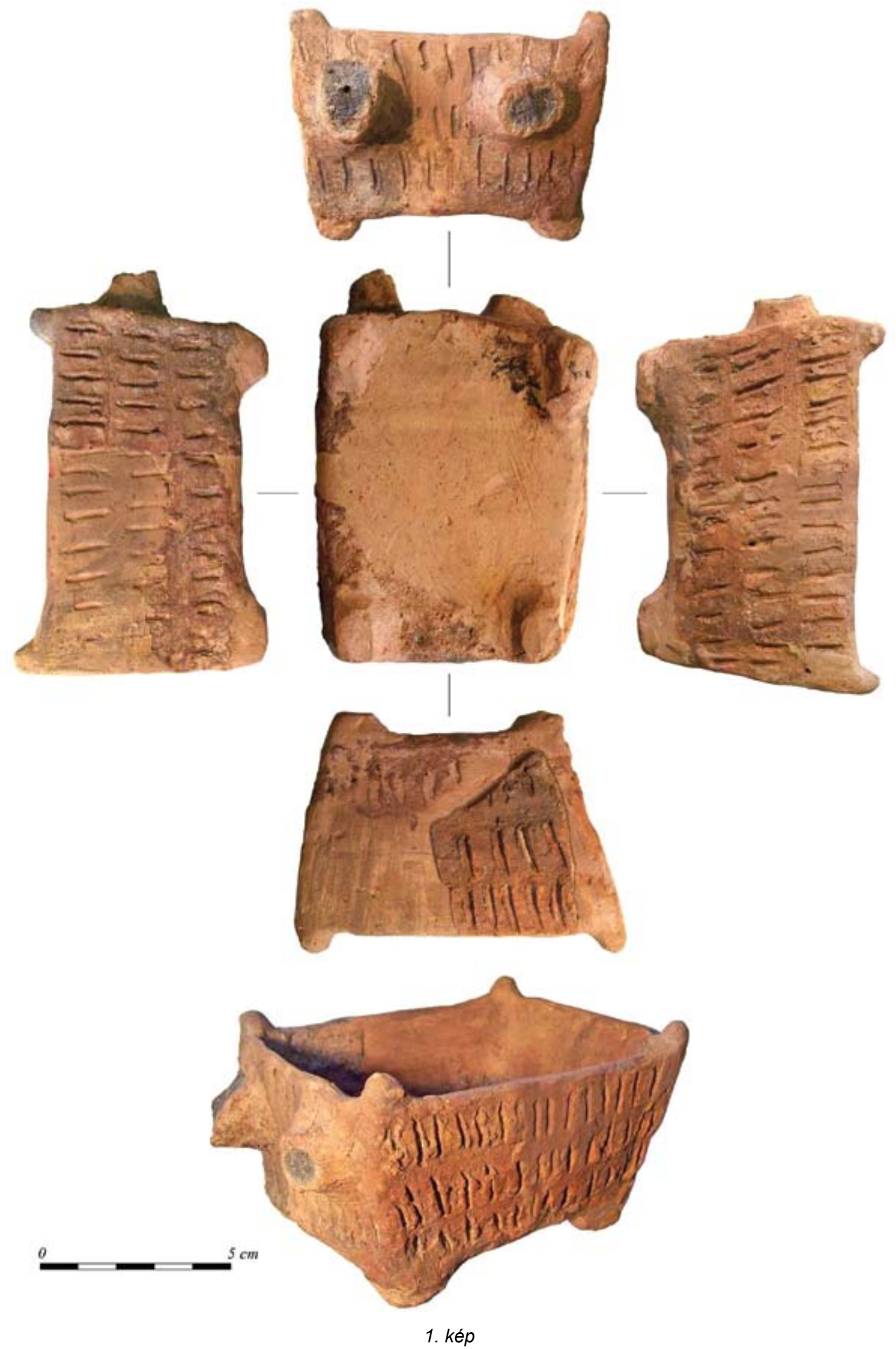



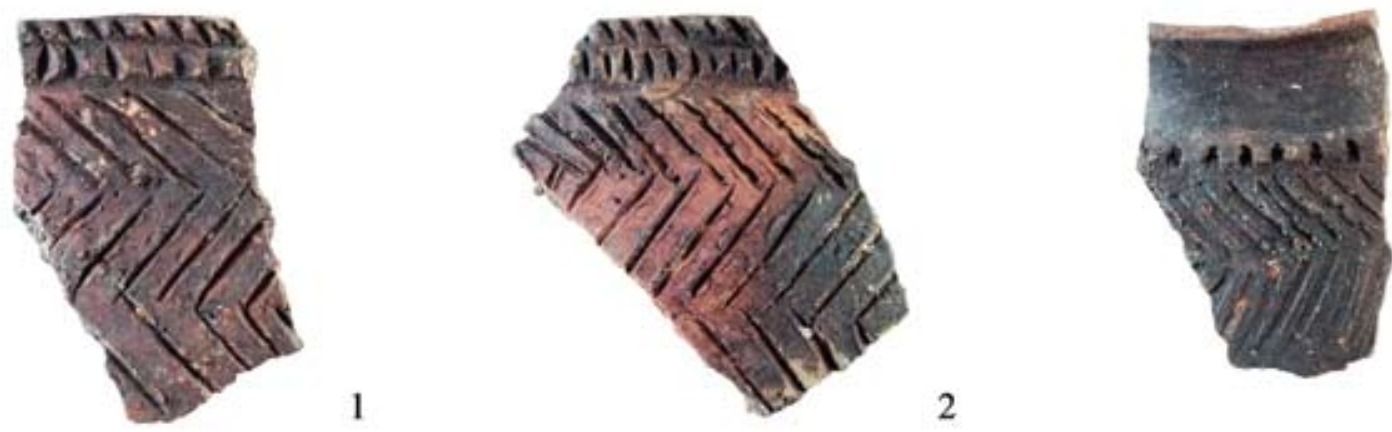

2

3
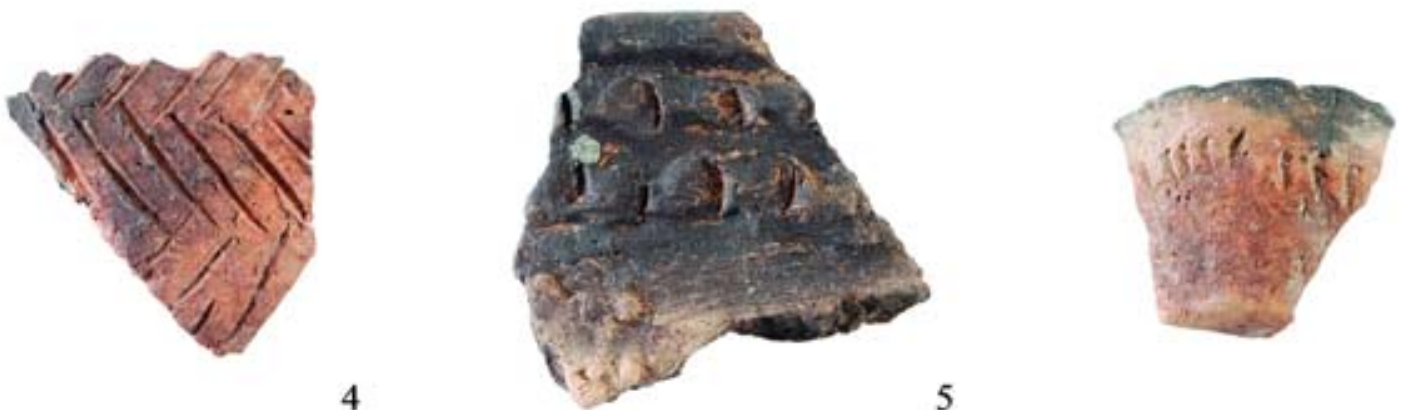

4
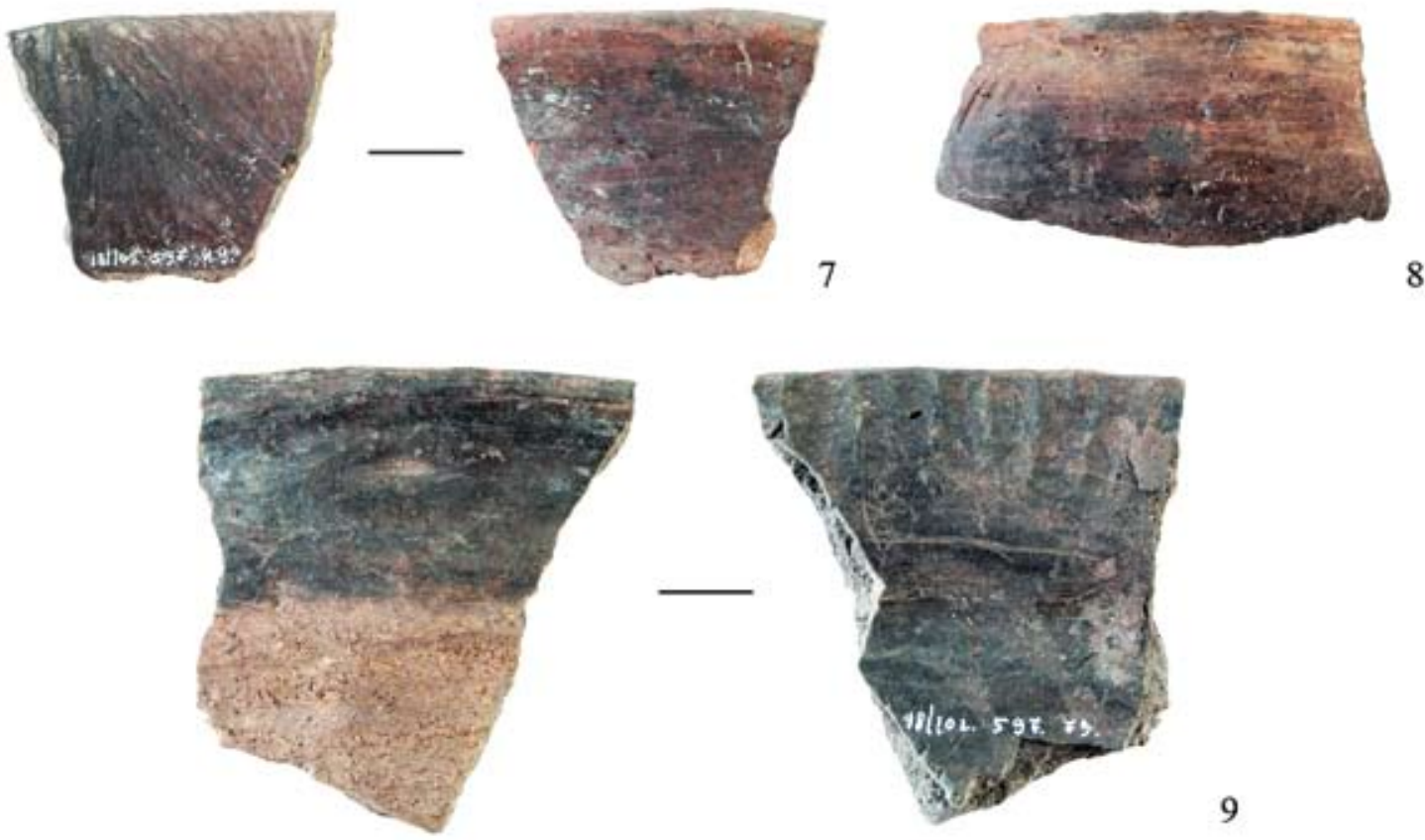

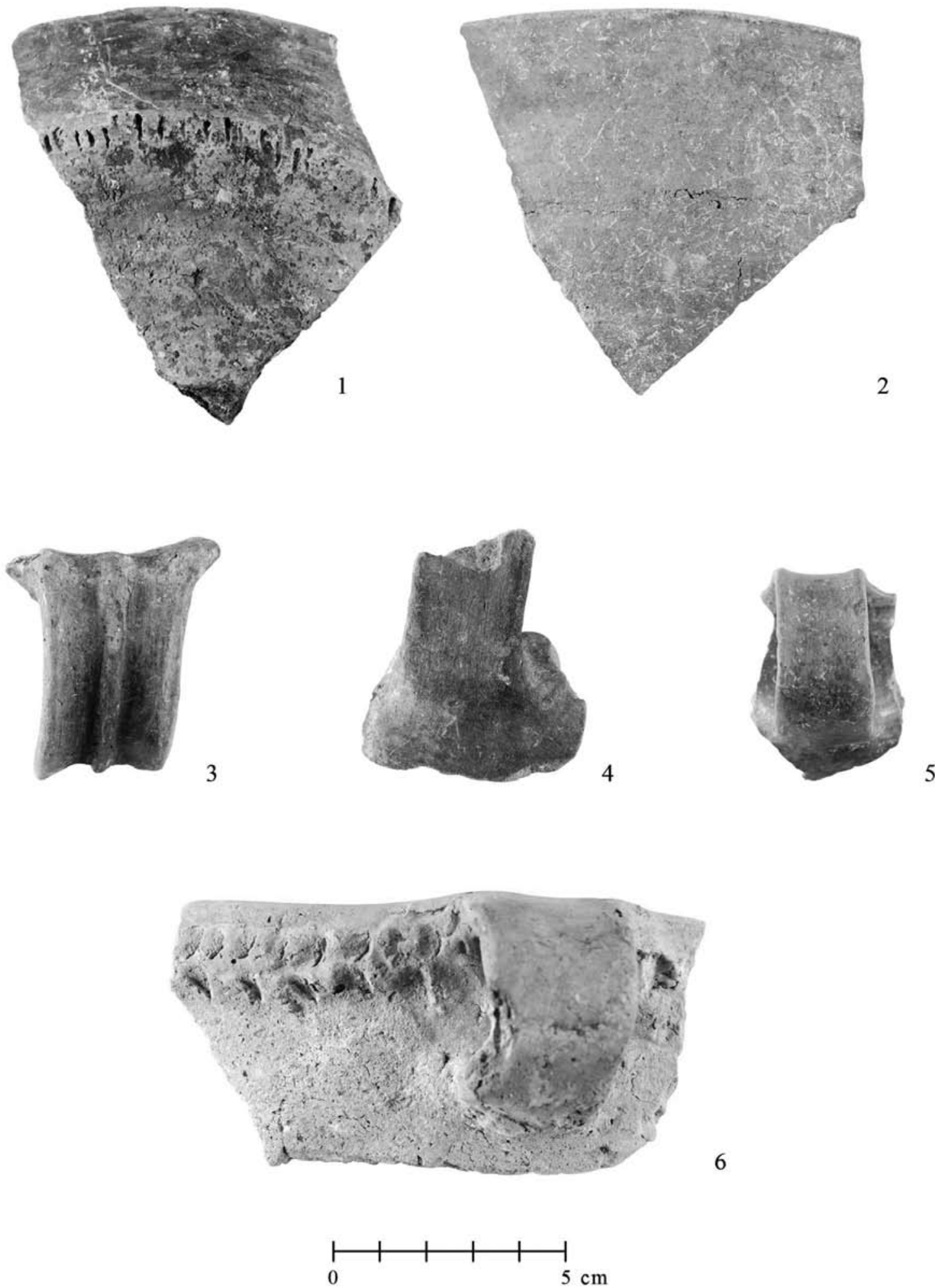
